\title{
Improving Students`Critical Thinking Through E-Book on Project-Based Learning in Vocational High School
}

\author{
Marini Fitri Rahmawati ${ }^{1}$, Siswandari ${ }^{2}$, Lukman Hakim ${ }^{3}$
}

\begin{tabular}{l} 
ARTICLE INFO \\
\hline Article History: \\
Received 04.07.2018 \\
Received in revised form \\
24.08 .2018 \\
Accepted \\
Available online 01.10 .2018
\end{tabular}

\begin{abstract}
This study aims to describe the use of e-book based on project based learning in improving students' critical thinking in inventory materials in VHS. This type of research is a quantitative descriptive study with a case study method. The sample of this research used 30 students in SMK Batik 1 Surakarta. The sampling technique uses simple random sampling technique, while the data collection technique used is essay test. The essay question is made in accordance with the indicators of critical thinking, namely analyzing, evaluating, and creating. The results showed that before using e-book based on project based learning only $8.3 \%$ of students were able to analyze, $50 \%$ evaluate, and $40 \%$ created. However, after using the e-book, students who were able to analyze increased to $55 \%$, evaluated $93.3 \%$, and created $76.7 \%$. any as $10 \%$ have enough critical thinking. So, the use of e-book based on Project Based Learning can increase students' critical thinking.
\end{abstract}

(C) 2018 IJERE. All rights resened

Keywords: ${ }^{1}$

E-Book, Critical Thinking, Project Based Learning.

\section{INTRODUCTION}

$21^{\text {st }}$ century is the era in which information and technology reign supreme. Holm berg (2018) stated that Information and Communication Technologies (ICT) serve as a mean of support in teachers 'learning goals, learning processes and as a representation of knowledge product. So it can be concluded that education today cannot be separated from technological advancement. Lindquist (2011) added that technology can help learners overcome various learning problems and can be developed to suit learners ' needs. The rapid development of Information and Communication Technology (ICT) today requires learning materials development to shift from conventional to ICT-based learning. Learning resources are all components of instructional systems that are specifically designed and utilized in learning activities (Warsita, 2008). Learning success depends on the accuracy of teachers in utilizing technology to suit learning objectives and creating meaningful learning experience for students (Wankel \& Blessinger, 2015), teachers can use a variety of learning media that match the learning needs and objectives.

Siqueira, et al (2016) \& Buckingham (2008) suggest that learning media is a tool to deliver learning material in the form of text, audio, or visual images to assist learning activities. One of the learning media that can be used by teachers in the current technological era is e-book. E-book is one of the innovations in learning resources that takes form of electronic format containing information that in either text or images (Ismawati, 2012). The e-book issued by the Ministry of National Education (2008) came in the form of Portable Document Format (pdf). One of the advantages of e-books is that they can be easily and cheaply found. In addition, e-books can be accessed anywhere and anytime through devices that students already have, such as smartphones, laptops, or tablets. Hong, Trimi, and Kim (2016) Smartphones, tablets, laptops are one of the available technologies that can be utilized to improve the quality and ea se of life, as well as social life trends.

There are two activities that take place in the learning process, learning and teaching activities. One way to improve the quality of learning is the amount of exposure of the students to learning resources (Kamsinah: 2008). The 2013 Curriculum Development Team (2013) states that learning resources can be in the form of printed or electronic media, surrounding environment or other relevant learning resources. The results of the research conducted by Wu \& Chen (2011); Cheng, et al (2012), shows that electronic books or ebooks have special values or interest to the students, especially in terms of cost because it can be accessed

1 marinifr2@gmail.com, orcid.org/0000-0001-6741-5655 
Ra hmawati,M.F., Siswandari, Hakim,L. (2018).Improving students`critical thinking through e-book on project-based learning in voca ti onal high school. International Journal of Educational Research Review,3(4),118-127.

through smartphone. With the e-book, students can easily complete the tasks given by the teacher. Furthermore, Jindal \& Pant (2013) added that using e-books has a positive impact on students and helps students in the teaching and learning process in the classroom, this study also found that the use of e-books was relatively high compared to or dinary textbooks.

Education in Indonesia based its curricula on the 2013 Curriculum. The 2013 curriculum requires the creativity of the teachers in delivering learning activities. One of the requirements is that the teacher must be able to promote active participation of the students in their learning activities. The following are the characteristics of learning strategies in the 2013 curriculum that are necessary to be implemented in the classroom : (1) learner-centered (student centered); (2) learning through action, students actively doing their learning; (3) emphasizing in researching, discovering and creating; and (4) learning through a contextual approach (Hosnan, 2014: 85). A creative teacher, who is able to develop students' thinking skills, is imperative. In order to foster students' thinking skills, a teacher should also pay attention to the learning model. Teachers should choose a more varied learning model, which can encourage students to actively get involved in their learning experiences. The learning process should be appropriate between the learning model and the needs of students, in order for the learning to become more meaningful and interesting. Therefore, teachers need to create enjoyable learning experience (Arends, 2011: 24 and Bhattacha rjee, et al: 2018).

Hosnan (2017) explained that the Project Based Learning (PBL) model is a learning model that emphasizes student-centered learning in a project. One of the objectives of the Project Based Learning model (PBL) is to train students 'critical thinking and encourage them to be able to solve a problem (Sumarni, 2012). Project Based Learning (PBL) learning models can improve students' critical thinking skills, while they are doing the tasks in the project.

Masykur and Daniel (2016) suggest that there are differences between critical thinking skills in the classes taught based on Project Based Learning (PBL) learning models compared to classes that are not, and there is a significant increase in the results of cognitive learning and critical thin king skills of students after the application of the Project Based Learning model (PBL). Yanti, et al (2013) added that the Project Based Learning (PBL) model had a significant effect on students' critical thinking skills. These previous studies assumed that knowledge is constructed from the learner themselves or commonly known as constructivism. Seeing the various successes of the implementation of constructivism learning models, it is necessary to implement a wider implementation as an effort to improve the quality of education and one of them is the development of e-books based on project based learning.

Based on said premises, students need learning that combines face-to-face learning and ICT-assisted learning (Weil \& Silva, 2014). The advantage of using e-books according to (Santoso, Siswandari \& Sawiji, 2018) e-books are easy to access, no need to go to the library, easy topic search, can be accessed anywhere and any time, display is better, cheaper and saves space deviation. The use of e-books based on project based learning is expected to be an alternative media in financial accounting learning to increase students' critical thinking. E-book based on project based learning is designed with an attractive appearance and includes syntax of project-based learning, material, sample questions, and student learning evaluations in the form of electronic books. The concept of interesting and fun learning media that can provide a direct learning experience is suitable for students according to their learning conditions and needs. E-book based on project based learning is a combination of technology-assisted learning media, information, and communication with learning models that simultaneously provide information regarding financial accounting learning materials to students.

The financial accounting material used in this study is inventory accounting material for students of senior high second grade (Class XI) of accounting vocation. Inventory of merchandise is a stock of goods stored for use or sale in coming period to facilitated production (Harding, 2001; Kusuma, 2009). In this material, students are required to be able to evaluate the definition and classification of inventories, differentiate inventory classification and recording systems, as well as differentiate the methods used to determine inventory value, to design inventory cards to calculate inventory values with periodic systems and perpetual systems. By studying this material, students would be better equipped in dealing with the work in the field of accounting and financial institutions. This material was chosen because based on the 
Rahmawati,M.F., Siswandari, Hakim,L. (2018).Improving students `critical thinking through e-book on project-based learning in voca ti onal high school. International Journal of Educational Research Review,3(4),118-127.

results of the initial interview with 64 students of class XI Accounting Vocation at SMK Batik 1 Surakarta as much as $65.62 \%$ of students stated that inventory accounting material $w$ as a material that was difficult to understand. Therefore, this study aims to describe the use of e-book media based on project based learning in increasing students ' critial thinking on inventory accounting materials in Vocational High Schools.

\section{METHOD}

This research is a quantitative descriptive research with a case study method. The study was conducted at Surakarta Batik 1 Vocational School. Surakarta Batik Vocational School 1 is one of the Private Vocational Schools which has an accredited accounting proficiency and has ISO 9001: 2008. In addition, the curriculum used is the 2013 curriculum. The existing facilities and infrastructure of the school also support IT-based learning.

The subjects of this study were students of Class XI Accounting who had learned inventory accounting materials. The sample was 30 students, students consisting of 2 males and 28 females who were selected using simple random sampling technique. This technique is used because all students in the population get the same material with the same model and learning media and curriculum which created a homogeneous population. The chosen students were initially tested before using e-books, later their learning began to utilize e-books and then given a final test to find out their state of understanding. Data was collected using test, by using test the data obtained were quantitative data. In addition, observations and interviews were conducted to find out the students` opinions regarding the benefits of using e-books in learning.

The instruments used in this study were essay test questions that were analyzed quantitatively, and the observation sheets and interview sheets were analyzed descriptively. Essay test are tests that contain w ritten questions which answers are composed of essays (essays) or long sentences (Purwanto, 2010). Essay tests were chosen because this form of test is suitable to test general knowledge that matches the characteristics of the inventory accounting material. Test scoring uses point method because the essay test used is essay test with limited number of answers. This essay tests 'answers can be formulated with a limited (specific) answer guidelines so that the weight of each question can be determined.This study uses essay test questions that aim to reveal the data of students' critical thinking skills regarding inventory accounting material.

The results obtained from the test will be analyzed by giving a score on each question according to the scoring guidelines that have been made. The score is then calculated using the percentages correction formula (Purwanto, 2010). Then the value is interpreted based on the criteria for interpreting critical thinking of students in table 1.

Table 2. Interpretation Criteria for Students' Critical Thinking

\begin{tabular}{ccc}
\hline Assesment & Letter & Interpretation \\
\hline $0-30$ & E & Very Poor Critical Thinking \\
$31-55$ & D & Poor Critical Thinking \\
$56-65$ & C & Enough Critical Thinking \\
$66-79$ & B & Good Critical Thinking \\
$80-100$ & A & Excellent Critical Thinking \\
\hline
\end{tabular}

Source: (Purw anto, 2010)

\section{FINDINGS}

Efforts to increase critical thinking of students through the use of e-book media based on project based learning on financial accounting subject showed satisfactory results. As many as $66.7 \%$ of the 30 students who were tested were able to exceed the Minimum Completeness Criteria of financial accounting subjects of 78 after using e-books based on project based learning. Before using e-books based on project based learning, students have not been able to achieve the minimum criteria. Essay test questions used as a test consist of 5 questions regarding inventory accounting material. Based on the definition of critical thinking as described above, thinking levels of Bloom's Taxonomy can be used to measure critical-thinking skills because the activities of analysing, evaluating, and creating are included in the cognitive domain of Bloom's Taxonomy (Saputra, Joyoatmojo \& Wardani, 2018). The question is made based on indicators of learning objectives that 
Rahmawati,M.F., Siswandari, Hakim,L. (2018).Improving students `critical thinking through e-book on project-based learning in voca ti onal high school. International Journal of Educational Research Review,3(4),118-127.

must be achieved by learners; evaluating the understanding of inventory, differentiating inventory classification and its recording system, distinguishing the methods used to determine inventory value, evaluating the use of methods in determining inventory value, and designing inventory cards to calculate value stock. Detailed explanations about critical thinking of students in working on essay questions on financial accounting material for each item are as follows:

\section{Evaluating the understanding of inventory}

The first item in the essay test aimed to the evaluate students ' understanding of supplies. Students are asked to evaluate the understanding of inventory. The maximum score obtained by students if they are able to answer the first question correctly is 10. Critical thinking of students in answering the indicator of this question can be described in Figure 1 below:

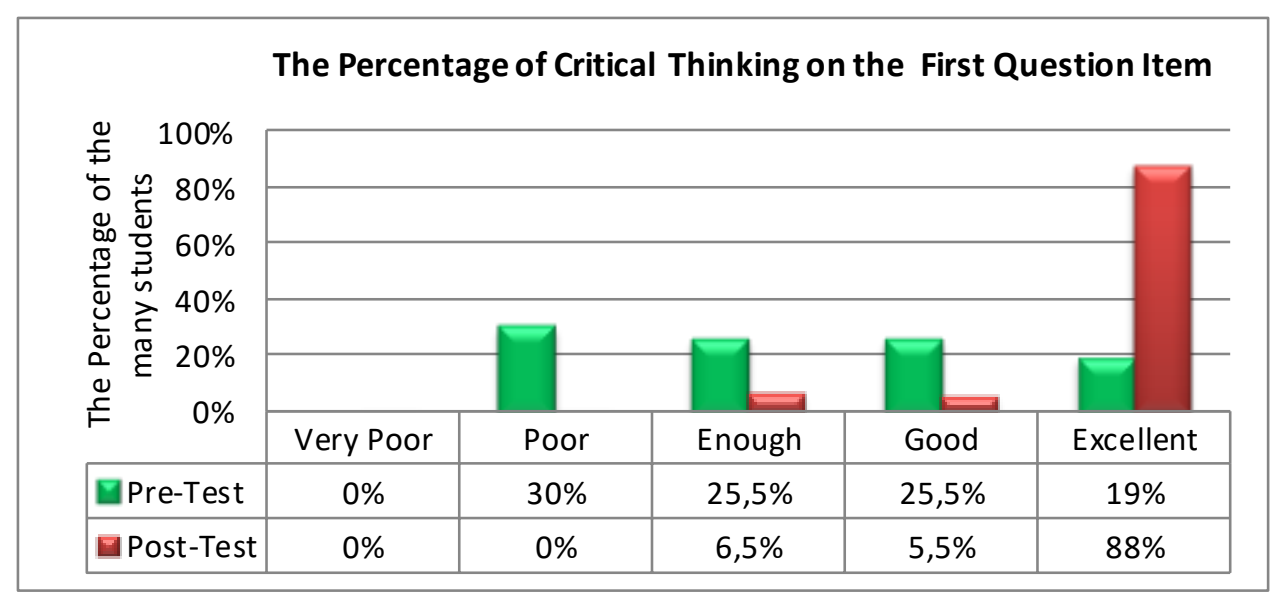

Figure 1. Critical Thinking of Students in the First Question Item

Based on data presented on Figure 1, there is an increase in students' critical thinking on the evaluation of the understanding of inventory before and after using e-books based on project based learning. Prior to using the e-book, students grouped at the category of excellent critical thinking were only $19 \%$, satisfactory critical thinking $25.5 \%$, good critical thinking $25.5 \%$, and poor critical thinking at $30 \%$. These results indicated that some students did not have adequate critical thinking about the understanding of supplies. Students felt that inventory accounting material was difficult; in addition, the media used in learning were only textbooks which led them to not having interest in learning and failed understand the indicators of the first question. How ever, some of the other students already had good critical thinking that enabled them to fully evaluate the understanding of supplies.

Subsequently, after using e-book based on project based learning, the percentage of students ' critical thinking increased. $88 \%$ of the students have excellent critical thinking, $5.5 \%$ good and $6.5 \%$ have satisfactory critical thinking. These results showed that after using e-book, the majority of students 'critical thinking on evaluating the understanding of inventory experienced a certain rate of increase. Students strongly believed that e-book based on project based learning is an interesting media and helped them to memorize and evaluate the understanding of inventory more easily. Therefore, after using e-book based on project based learning, it can be concluded that students have had complete critical thinking about the understanding of inventory.

\section{Differentiating inventory classification and its recording system}

The second item in the essay test given to students aimed to see their ability in differentiate between inventory classification and its recording system. Students were asked to differentiate inventory classification and its recording system. The maximum score obtained by students if they were able to answ er the second question correctly is 15 . Critical thinking of students in answering the question can be illustrated in Figure 2 below: 
Rahmawati,M.F., Siswandari, Hakim,L. (2018).Improving students `critical thinking through e-book on project-based learning in voca tional high school. International Journal of Educational Research Review,3(4),118-127.

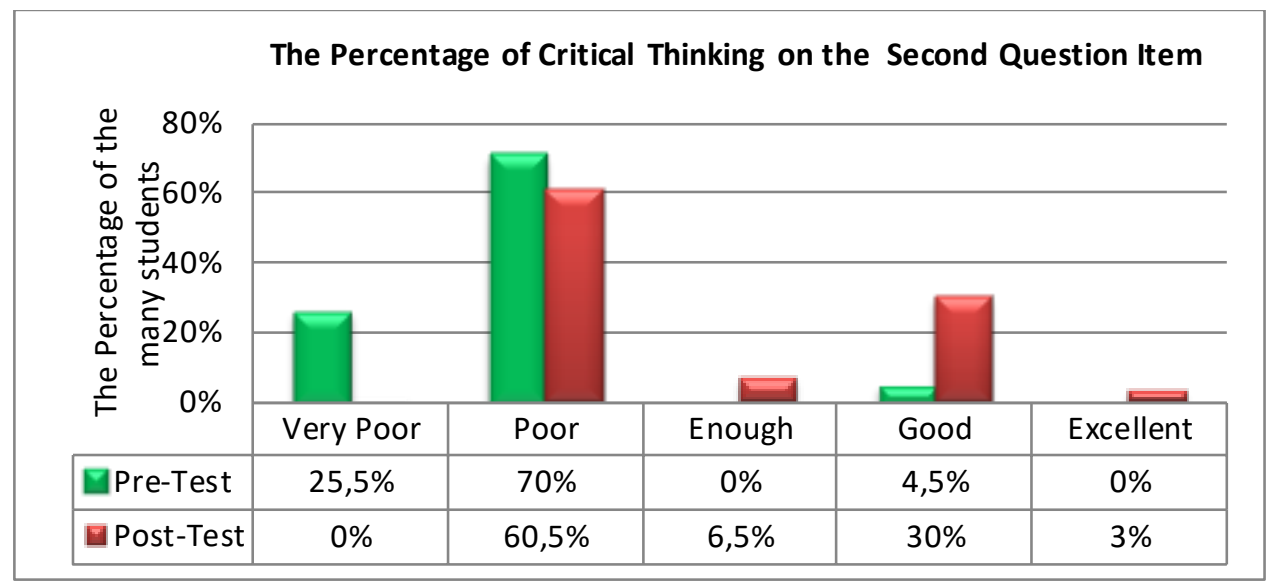

Figure 2. Critical Thinking of Students in the Second Question Item

Based on Figure 2, students had poor critical thinking in answering questions on indicators of differences in inventory classification and recording systems. $70 \%$ had poor critical thinking, only $4.5 \%$ of students had good critical thinking, the remaining $25.5 \%$ had an alarming deficient in critical thinking. This numbers proved that students were yet to master and be able to differentiate in ventory classification and recording systems that they cannot describe the differences. Part of the reason was the terms used in textbooks were too difficult to understand thus led them unable to accurately interpret those terms.

After using e-book based on project based learning, students ' critical thinking increased to 3\% of the students having excellent critical thinking, 30\% having good critical thinking, $6.5 \%$ having enough critical thinking, and $60.5 \%$ still lacking adequate crtitical thinking. These results indicated an increase in critical thinking on the differences in inventory classification and recording systems after using e-book based on project based learning. Although some students still have less than satisfactory critical thinking, students have been able to describe and distinguish inventory classification and recording systems though still too simple that they cannot get the maximum score on the second question. Students felt that by using e-books based on project based learning, differences in inventory classification and recording systems are easier to understand than by textbooks learning.

\section{Distinguishing the methods used to determine inventory value}

The third item in the essay test related to the different methods used to determine the value of inventory. Students were asked to distinguish the methods used to determine the value of inventory. The maximum score obtained by students for answering correctly is 20. Critical thinking of the students in answering the indicator of this question can be illustrated in the following figure 3 :

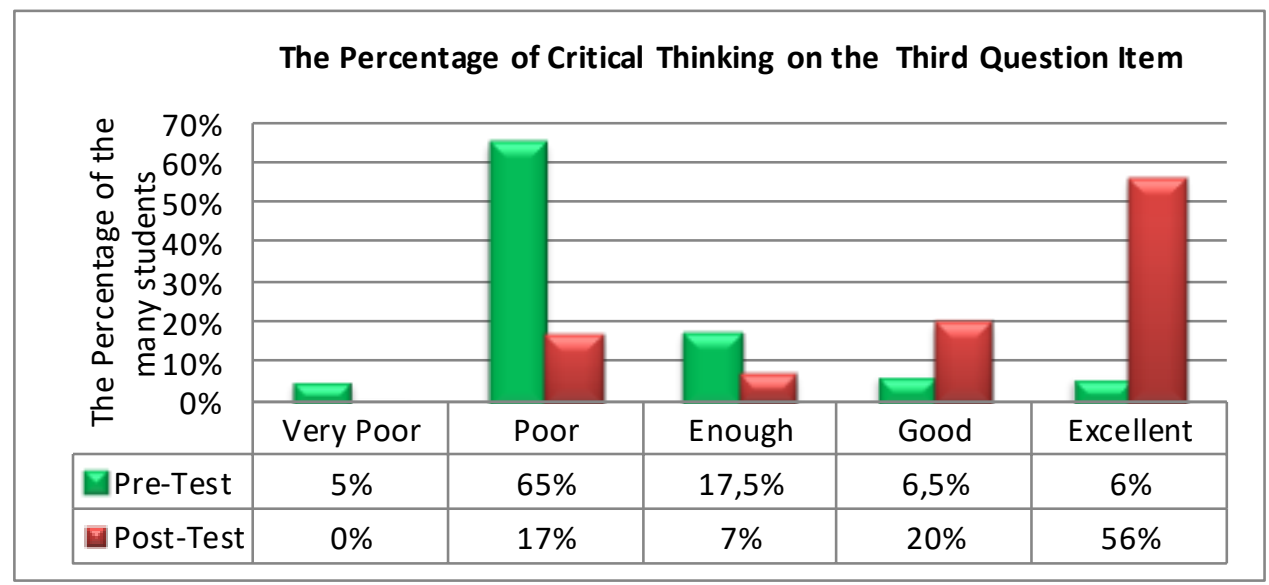

Figure 3. Critical Thinking of Students in the Third Question Item

Based on Figure 3, there is an increase in the difference indicator of the methods used to determine the value of inventory. Based on the percentage of critical thinking of the students before using e-book were; $5 \%$ had very poor critical thinking, $65 \%$ poor critical thinking, $17.5 \%$ had enough critical thinking, $6.5 \%$ had 
Rahmawati,M.F., Siswandari, Hakim,L. (2018).Improving students `critical thinking through e-book on project-based learning in voca ti onal high school. International Journal of Educational Research Review,3(4),118-127.

good critical thinking, and 6\% had excellent critical thinking. Students felt that they have not been able to find differences in the methods used to determine the value of inventory, because in the textbooks only implied supposed difference. Students tend to memorize material and have not been able to conclude and find the connection to the material being studied.

Whereas after using e-book based on project based learning, the percentage of students 'critical thinking increased to $17 \%$ having less understanding, $7 \%$ had enough critical thinking, $20 \%$ had good critical thinking, and $56 \%$ had excellent critical thinking. These results indicated that after using e-books based on project based learning students were able to answer questions in a complete manner and had good critical thinking compared to before they were not using e-books based on project based learning.

\section{Evaluating the use of methods in determining inventory value}

The fourth item in the essay test focused on the evaluation of the use of methods in determining inventory value. Students were asked to evaluate the use of methods in determining inventory value. The maximum score obtained by students if they answered the third question cor rectly is 15 . Critical thinking of the students in answering this question can be described in Figure 4 below:

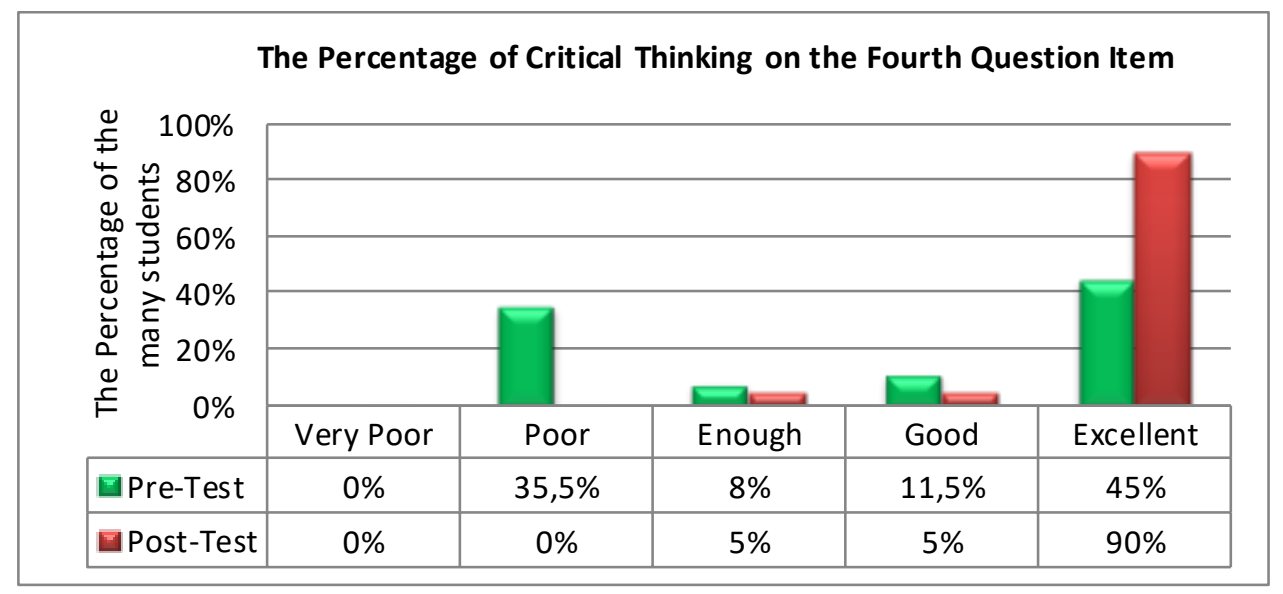

Figure 4. Critical Thinking of Students in the Fourth Question Item

Based on Figure 4, there is an increase in the evaluation indicator of the use of methods in determining inventory value. This can be seen from the percentage of students' critical thinking before using e-book based on project based learning. $35.5 \%$ having poor critical thinking, $8 \%$ have enough critical thinking, $11.5 \%$ having good critical thinking, and $45 \%$ having excellent critical thinking.

The reason why students have not been able to evaluate the use of the method in determining the value of inventory was because in the textbook used, the mean of determining the value is not implied. Students tend to memorize material and yet have to be able conclude and find correlation to the material being studied. While after using e-book based on project based learning the percentage critical thinking of students increased, $5 \%$ has enough critical thinking, $5 \%$ has good critical thinking, and $90 \%$ has excellent critical thinking. These results indicated that after the use of e-books based on project based learning, students were able to answer questions in a complete manner compared to before using e-books based on project based learning.

The increase in critical thinking happened because students felt that they have a clearer picture of the material of merchandise inventory so that they can evaluate the use of methods in determining inventory value. The description was obtained by students in the illustrations presented in the form of examples of available problems in e-books based on project based learning.

\section{Designing inventory cards to calculate value stock using Periodic System and Perpetual System}

The item in the essay test related to the inventory card design to calculate the value of inventory with a periodic system and a perpetual system. This last question consisted of two cases of transactions related to inventory of merchandise. At the first case, students were asked to make a periodic system inventory card design. The maximum score for answering the first case correctly was 15 . The second case required the students to calculate the inventory of merchandise according to the data on the inventory card that has been 
Rahmawati,M.F., Siswandari, Hakim,L. (2018).Improving students `critical thinking through e-book on project-based learning in voca ti onal high school. International Journal of Educational Research Review,3(4),118-127.

made in LIFO, FIFO, simple average, and weighted average. The maximum score was 25 . Thus the total score of the four essay items was 100. Critical thinking of students in answering the indicators of this item can be illustrated in the following figure 5 :

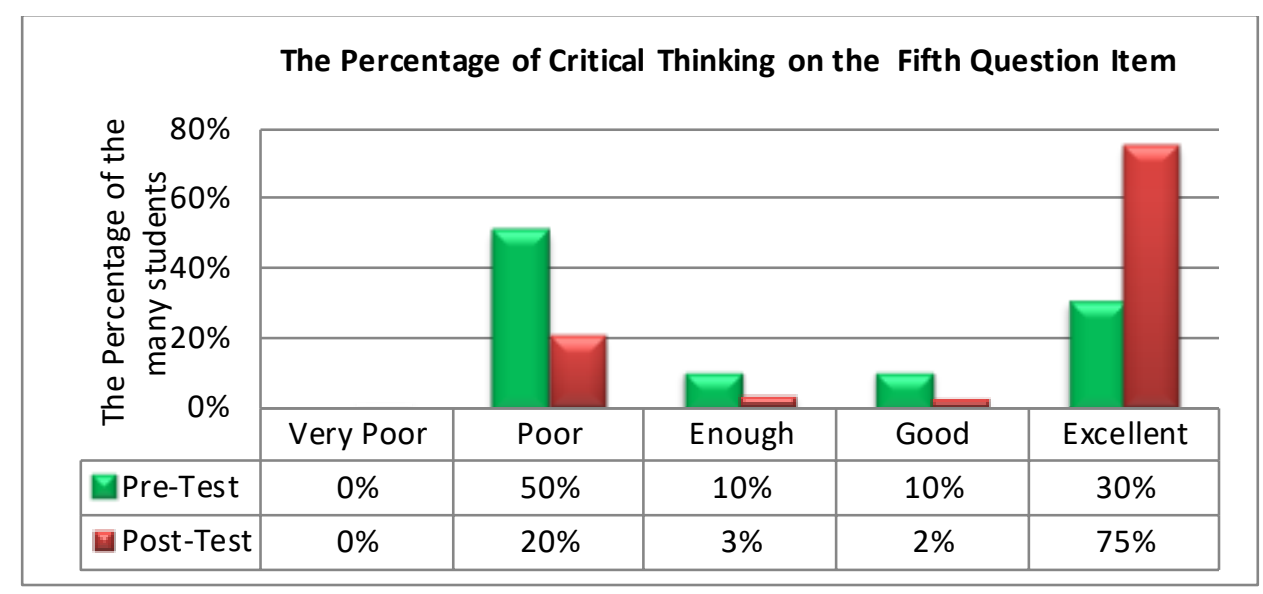

Figure 5. Critical Thinking of Students on the Fifth Question Item

Based on Figure 5, students ' critical thinking about the inventory card design and to calculate the value of inventory with a periodic system and a perpetual system proved to have an increased percentage. Before e-books based on project based learning were used, the percentage in the category of critical thinking were; $50 \%$ had poor critical thingking, $10 \%$ had enough critical thinking, $10 \%$ had good critical thinking, and 30\% had excellent critical thinking. Due to students' inability to understand how to calculate inventory value with the periodic system and perpetual system properly, students had difficulty in designing and completing the inventory card design.

Based on the minimum completeness criteria (KKM) that have been set by the school that is equal to 78 . Students who achieve a score of 78 have a category of good and very good critical thinking, while students who have not achieved that value, fall into the category of very lacking, lacking, and sufficient . The results showed that before using e-books based on project based learning students who were able to analyze by $8.3 \%$ and those who were not ableby $30 \%$, students, who were able to evaluate $50 \%$ and those who could not afford by $91.7 \%$, and students who were able created by $40 \%$ and who have not been able to by $60 \%$.

Furthermore, after using the e-book, students who were able to analyze increased to $55 \%$ and those who were unable to reach $45 \%$, students who w ere able to evaluate by $93.3 \%$ and those who were unable to afford by $25 \%$, and students who were able to create $76.7 \%$ and those who have not been able to reach $23.3 \%$. So, the use of e-books based on Project Based Learning in learning in vocational schools can increase students' critical thinking. This shows that in general the use of e-book media can increase students' critical thinking on inventory accounting material.

\section{RESULT, DISCUSSION, AND SUGGESTIONS}

The overall results of the study reinforced the fact that before using a project based learning e-book, $60 \%$ of the 30 students had poor critical thinking. Only $16.7 \%$ of the students had good critical thinking, while the remaining $23.3 \%$ had only enough critical thinking. After the learning using e-books based on project based learning, students who have good critical thinking saw an increase to as much as 50\% and 33\% had excellent critical thinking. Only $7 \%$ of the 30 students had poor critical thinking and the remaining $10 \%$ had enough critical thinking.

The ability to think critically is one of the abilities that are needed in solving problems. There are certain characteristics that can be observed to know the level of critical thinking ability. This characteristic was stated by Tung (2015); critical thinking (critical thinking skills) in the form of evaluating, analyzing, and linking connections. Students that are able to think critically can be seen when they can evaluate, analyze and link the relations between learning material provided by the teacher and its application in the real world. Students that are able to connect academic content $w$ ith the real world, w ould have more enthusiasm 
Ra hmawati,M.F., Siswandari, Hakim,L. (2018).Improving students`critical thinking through e-book on project-based learning in voca tional high school. International Journal of Educational Research Review,3(4),118-127.

to actively participate in learning activities, which will help students' critical thinking skills to be honed and improved (Johnson, 2014). Increased mastery of the students' competencies is a manifestation of the results of the learning activities delivered by the teacher.

The use of e-books based on project based learning in inventory accounting materials can provide variations in financial accounting learning and facilitate students to understand the material by providing direct learning experiences increase their interest, activeness, and interaction in order to improve their critical thinking. Increased critical thinking could facilitate both teachers and students in achieving learning goals. The benefits of using e-books based on project based learning as an ICT-based learning media in vocational schools could also familiarized teachers in the use of ICT in learning. Effor ts to improve teachers' ability to learn and use IT-based learning media is necessary in order for the teachers to comfortably integrate IT in the learning process (Destiana \& Soenarto, 2014).

Thus, the use of e-books based on project based learning has been proved to effectively be used in financial accounting learning because it can increase students' critical thinking. The use of e-book media based on project based learning proved to be a positive and effective way to help students in their learning process and to motivate them to be more active and independent learning process (Jindal \& Pant, 2013; Wu \& Chen, 2011) and in turn help the teachers to act as a facilitator in learning, that is tasked with helping and directing students should the learning material proved to be difficult for the students. Such learning conditions are in line with the demands of the 2013 curriculum, which emphasized on the students' development (student centered). In addition, e-books are also more manageable to be used by the students. Attractive layout and the ease of operation on media such as smartphones, laptops or computers make this media more flexible. The display of e-book based on project based learning used in this study is presented in figure 6 .
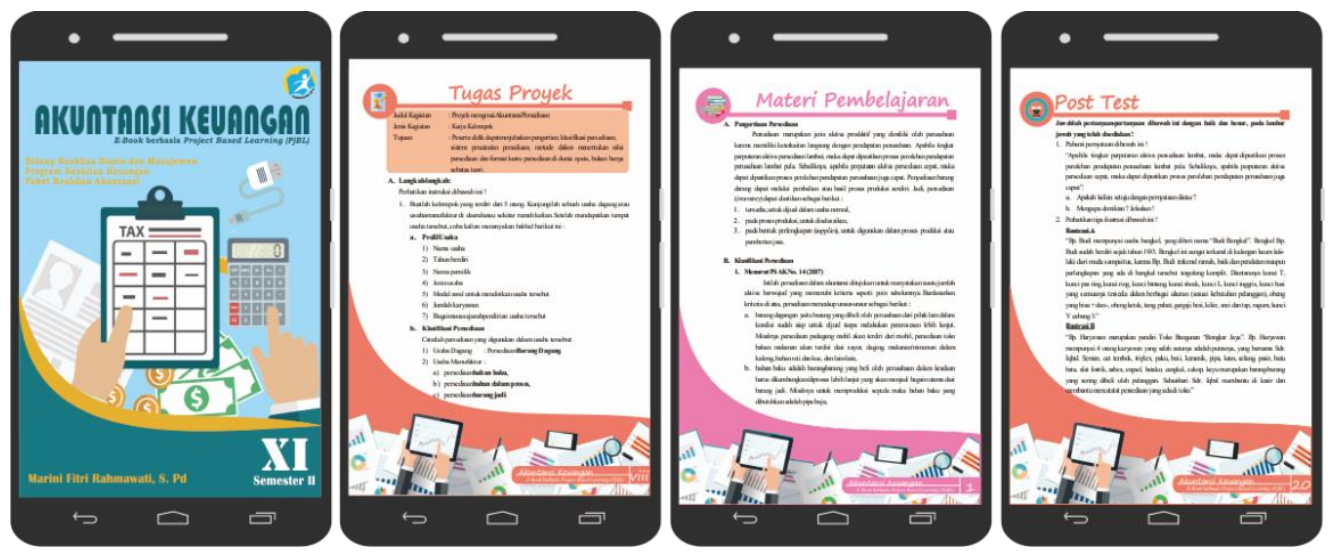

Figure 6. E-Book Display based on Project Based Learning

Based on the discussion it can be concluded that the use of e-books based on project based learning is proven to increase students' critical thinking (Jindal \& Pant, 2013; Wu \& Chen, 2011). This is proved by the increase in students ' critical thinking answering questions and designing inventory cards to calculate the value of inventory with a periodic system and a perpetual system. E-book learning media based on project based learning in inventory accounting materials can be a complement, alternative, and variant of learning media in Vocational High Schools in Accounting Expertise programs. The use of e-books based on project based learning can create fun learning and raised students ' curiosity and motivated them to be more active and independent in learning process. Such learning conditions fulfill the demands of the 2013 curriculum, which centered on the development of the students (student centered).

This research is only limited to assessing the increase in critical thinking of students by using e-book based on project based learning in financial accounting subjects at Surakarta Batik 1 Vocational School. The Headmaster as the manager and person in charge of the implementation of learning in the school is expected to maximize schools ' facility and infrastructure to at least support the IT-based learning process. Therefore, the headmaster should motivate the teachers to be able to develop innovative and creative learning through training and workshops. Teacher as the implementer of learning activities should start to use IT in their learning programs according to the demands of the curriculum, starting with the use of e-book media based 
Rahmawati,M.F., Siswandari, Hakim,L. (2018).Improving students `critical thinking through e-book on project-based learning in voca ti onal high school. International Journal of Educational Research Review,3(4),118-127.

on project based learning on inventory accounting materials. While the next researcher, should expand the learning material and expand the school that will be used for research. Subsequent researchers can also create e-books with other learning models, subjects, and at other levels of education.

\section{REFERENCES}

Bhattacharjee, D., Paul, A., Kim, J., H. \& Karthigaikumar, P. (2018). An immersive learning model using evolutionary learning. Computers and Electrical Engineering, 65, 236-249.

Bhattacharjee, D., Paul, A., Kim, J., H. \& Karthigaikumar, P. (2018). An immersive learning model using evolutionary learning. Computers and Electrical Engineering, 65, 236-249.

Buckingham, D. (2008). Media education. Malden: Polity Press.

Cheng J., Huang, E., dan Lin, C.(2012). An e-book hub service based on a cloud platform. Review of Research in Open and Distance Learning (IRRODL), 13 (5), 39-55.

Daniel, F. (2016). Kemampuan Berpikir Kritis Siswa Pada Implementasi Project Based Learning (PJBL) Berpendekatan Saintifik. Jurnal Pendidikan Matematika Indonesia, 1, (1), 7-13.

Departemen Pendidikan Nasional (2008). Pengembangan bahan ajar dan media. Jakarta: Depdiknas.

Destiana, B. \& Soenarto. (2014). Faktor Determinan Pemanfaatan TIK dan Penga ruhnya Terhadap Kinerja Guru SMK di Kabupaten Gunungkidul. Jurnal Pendidikan Vokasi, 4, (3), 285-299.

Harding, J., H. (2001).Historical \& Mythological fiction. United States: Authors Choice Press.

Holmberg, C. (2018). Week intervention involving mobile based daily minute. Original Research, doi: 10.3389/fphys.2018.00423.

Hong, S. G., Trimi, S., dan Kim \& D. W. (2016). Smartphone use and internet literacy of senior citizens. Journal of Assistive Technologies, 10, (1), 27-38.

Hosnan, M. (2014). Pendekatan Saintifik dan Kontekstual dalam Pembelajaran Abad 21. Bogor: Ghalia Indonesia.

Ismawati, E. (2012). Telaah Kurikulum dan Pengembangan Bahan Ajar. Yogyakarta: Ombak.

Jindal, S., \& Pant, A. (2013). Availability of e-books in science: case study of University of Delhi. The Electronic Library, 31, (3), 313-328.

Johnson, E., B. (2014). Contextual Teaching \& Learning Menjadikan Kegiatan Belajar-Mengajar Mengasyikkan dan Bermakna. Bandung: Kaifa.

Kamsinah. (2008). Metode dalam Proses Pembelajaran. Lentera Pendidikan, 11, (1), 101-114.

Kusuma, H. (2009). Manajemen Produksi. Yogyakarta: PT. Andi.

Lindquist, J. (2010). Differential media: Multipurpose enteric screening media. http://www.jlindquist.net/generalmicro/dfmultinf.html, diakses tanggal 30 Mei 2018.

Masykur. (2016). Penerapan model project based learning Padamateri Klasifikasi Tumbuhan di MTsN Kuta Baro. Jurnal EduBio Tropika, 4, (2), 1-52.

Purwanto, M. G. (2010). Prinsip-Prinsip dan Teknik Evaluasi Pengajaran. Bandung: PT. Remaja Rosdakarya.

Santoso, T. N. B., Siswandari., \& Sawiji, H. (2018). The effectiveness of ebook versus printed books in the rural school Indonesia at the modern learning era. International Journal of Education Research Review, $3,(4), 77-84$.

Saputra, D. M., Joyoatmojo, S., \& Wardani, K. D. (2018). The Assesment of critical-thinking-tests for accounting students of vocational high schools. International Journal of Education Research Review, 3, (4), 85-96. 
Rahmawati,M.F., Siswandari, Hakim,L. (2018).Improving students ' critical thinking through e-book on project-based learning in voca tional high school. International Journal of Educational Research Review,3(4),118-127.

Siqueira, A. B. D., Berardi, A., Mistry, J., dan Rothberg, D. (2016). Experimenting with media education, civic engagement, and sustainability in brazilian schools. Studies in Media and Communications, 12, 41 61.

Sumarni. (2012). Metode Pembelajaran di Sekolah Dasar. Yogyakarta: Pustaka Pelajar.

Tim Penyusun. (2013). Kurikulum 2013: Kompetensi Dasar Sekolah Dasar/Ibtidaiyah. Jakarta: Kemendikbud.

Tung, K., Y. (2015). Pembelajaran dan Perkembangan Belajar. Jakarta: PT. Indeks.

Warsita, B. (2008). Teknologi Pembelajaran Landasan \& Aplikasinya. Jakarta: Rineka Cipta.

Weil, S. \& Silva, T. D. (2014). Blended learning in accounting: A New Zealand case. Meditari Accountancy Research. Vol. 22, (2), 224-244.

Wu, M., D., \& Chen S., C. (2011). Graduate student's usage of and attitudes towards e-books: Experience from Taiw an. Program, 45, (3), 294-307.

Yanti, D., E., Karyanto, P., \& Sugiharto, B. (2013). Pengaruh Model Project Based Learning (PjBL) terhadap Kemampuan Berpikir Kritis Sisw a Kelas X SMA Negeri 2 Karanganyar Tahun Pelajaran 2012/2013. Bio-Pedagogi, 2, (2), 92-99. 